\title{
IMPROVING ENVIRONMENTAL AWARENESS THROUGH A PARTICIPATORY FIELDWORK
}

\author{
Alviani Pemata \\ Duta Wacana Christian University Yogyakarta Indonesia \\ E-mail: alviani@staff.ukdw.ac.id
}

\begin{abstract}
This study aims to analyze the provision of field assignments for students to increase their awareness of the environment. This research is an analysis of students' assignments on fieldwork. This fieldwork was an assignment of a course called Ilmu Kealaman Dasar (Basic Natural Science), Faculty of Bussiness, Chirstian Duta Wacana University. This course aimed to enable students to increase their understanding and concern for the natural environment. Lecturing with a teachercentered approach is believed to be unable to achieve the expected lecture goals. Therefore, this approach needs to change by implementing a participative learning strategy. The implementation of this strategy involves students' participation in some activities. Thus, students can comprehend more of the course materials and enthusiastic in their learning process. This work used a text analysis approach by examining the results of student reflections on the vegetable planting process in an organic farm. From the data analysis, it can be seen that there is an increase in students' awareness and concern for the natural environment after they do fieldwork and there are hopes to participate in its maintenance.
\end{abstract}

Keywords: participatory, fieldwork, reflection, text analysis, basic natural science

\section{MENINGKATKAN KESADARAN TERHADAP LINGKUNGAN MELALUI TUGAS LAPANGAN YANG PARTISIPATORIS}

\begin{abstract}
Abstrak: Penelitian ini bertujuan untuk menganalisis pemberian tugas lapangan bagi mahasiswa untuk peningkatan kesadarannya terhadap lingkungan. Penelitian ini merupakan analisis tugas lapangan mahasiswa. Kerja lapangan ini merupakaan tugas mata kuliah Ilmu Kealaman Dasar mahasiswa Fakultas Bisnis di Universitas Kristen Duta Wacana. Mata kuliah ini bertujuan agar mahasiswa dapat meningkatkan pemahaman dan kepeduliannya terhadap lingkungan alam. Perkuliahan dengan pendekatan berpusat pada guru diyakini tidak dapat mencapai tujuan perkuliahan yang diharapkan. Oleh karena itu, pendekatan ini perlu diubah dengan menerapkan strategi pembelajaran yang partisipatif. Penerapan strategi ini melibatkan partisipasi mahasiswa dalam beberapa kegiatan. Dengan demikian mahasiswa dapat lebih memahami materi perkuliahan dan lebih antusias dalam proses pembelajaran. Penelitian ini menggunakan analisis teks berupa analisis Sarana Tanda dengan menelaah hasil refleksi mahasiswa tentang proses penanaman sayur di pertanian organik. Dari analisis data dapat diketahui adanya peningkatan kesadaran dan kepedulian para mahasiswa terhadap lingkungan alam setelah mereka melakukan tugas lapangan dan timbul harapan untuk berpartisipasi dalam pemeliharaannya.
\end{abstract}

Kata Kunci: partisipasi, kerja lapangan, refleksi, analisis teks, ilmu kealaman dasar

\section{INTRODUCTION}

The teaching and learning process in the classroom need to involve three aspects that create a balance of learning outcomes, such as aspects of cognition, psychomotor, and affection. The three aspects based on Bloom's theory are widely adopted in the fields of pedagogy and psychology. In terms of psychology, these three aspects are considered as the complete combination of human abilities in learning and developing the human brain. As for pedagogy, the three aspects of Bloom are ideally applied in the teaching and learning process and are shown in the use of verbs including the meaning of these three aspects 
in the learning objectives. Student learning outcomes need to be demonstrated through operational verbs in the list made by Bloom. For example, at the end of a lesson, students can identify the characteristics of a community in which they live; or at the end of a class, students can analyze situations that indicate an internal conflict in society. Even though the learning objectives have used verbs related to Bloom's taxonomy, choosing the right learning strategy for carrying out the learning objectives is very important.

The curriculum implementation can be proven through good learning activities in the sense of being effective and efficient. A learning activity shows an interaction between students and their learning environment, both with teachers, friends, tutors, learning media, and other learning resources. In other words, learning is a system that involves learning objectives, student interaction, and their learning environment, which also includes teaching materials, teaching methods, media, and evaluation. Learning in classrooms that have been going on so far generally uses a strategy that tends to be the same, making the teacher the only source of information, also known as teacher-centered. This teacher-centered learning results in teaching to be passive and learning to be effective for students. This monotonous, ineffective learning condition has been researched to make students incomplete learning. This proves the failure in the learning process at schools. Therefore, a learning innovation is needed that makes 'students as the center' (student-centered learning), creating a more active teaching and learning process (active learning strategy). Active learning strategies provide more opportunities for students to learn than just receiving lessons. In the active learning process, students construct their knowledge through their own learning experiences. Lecturers who act as facilitators should master the material and be able to communicate well, be innovative, and to be able to manage the class. Learning innovation is needed that makes 'students as the center' (student-centered learning), creating a more active teaching and learning process (active learning strategy). Active learning strategies provide more opportunities for students to learn than just receiving lessons. In the active learning process, students construct their knowledge through their own learning experiences. Lecturers who act as facilitators should master the material and be able to communicate well, be innovative, and to be able to manage the class. Learning innovation is needed that makes 'students as the center' (studentcentered learning), creating a more active teaching and learning process (active learning strategy). Active learning strategies provide more opportunities for students to learn than just receiving lessons. In the active learning process, students construct their knowledge through their own learning experiences. Lecturers who act as facilitators should master the material and be able to communicate well, be innovative, and to be able to manage the class. Students construct their knowledge through their own learning experiences. Lecturers who act as facilitators should master the material and be able to communicate well, be innovative, and to be able to manage the class. Students construct their knowledge through their own learning experiences. Lecturers who act as facilitators should master the material and be able to communicate well, be innovative, and to be able to manage the class.

This is related to what has been mandated by the Teacher and Lecturer Law of 
2005. Thus, every teacher and lecturer in Indonesia must have a minimum educational qualification of S-1 (undergraduate) for teachers and S-2 (postgraduate) for lecturers and have four competencies as professional teachers and lecturers, whether it be social, professional, personal, and pedagogical competences. Apart from these four competencies, social skills, ethics/ professionalism, creativity, cooperation, initiative, leadership, communication, critical thinking, and problem-solving are also required, all of them are categorized as soft skills.

As for research related to Basic Natural Sciences (IKD) courses, Surahman, Rachmat, \& Supardi (2016) have developed character education by integrating IKD courses and Islamic values through the Jigsaw strategy, discussion, and interpretation of the Islamic religion. Suja (2015), contributed five important things that deserve to be implanted in the students in IAD (IKD) courses, specifically being honest, caring about the environment, discipline, responsibility, and hard work. The research was conducted on twenty-five people who teach IAD (IKD) courses. The findings, one of which is caring for the environment, are very relevant to the research results of this student's reflection that has shown an awareness of preserving the natural environment.

Research on the success of teaching through assignments in IAD (IKD) courses was carried out by Yani \& Susanto (2019) that has succeeded in increasing student enthusiasm in learning through Mind Mapping assignments. Research that examines the results of the students' reflections using the content analysis method has so far not been found. Therefore, it is hoped that this research can contribute to an alternative form of the assignment given and the method usage as a way of analysis.

The purpose of this study is to prove that participatory assignments to the students can increase self-awareness and bring positive changes. In this case, the experience gained from the assignment is continued by writing it in the form of a reflection. Analysis of this reflection is used as the basis of evidence for this study through the Content Analysis method with the framework of Sign Vehicle Analysis.

\section{METHOD}

This analysis (Content Analysis) is one of the variations of text interpretation methods. The term 'Content Analysis' is included in Webster's Dictionary of the English Language in the early 1960s. many experts have been using this method for a long time in many fields such as philosophy, religious fields, anthropology, art, and psychology. Experts started to use this analysis method due to people realizing that languages, numbers, and symbols can be used as an instrument to interpret the behavior of human beings. For instance, in a speech, a leader would often repeat a phrase a few times, and by doing so the people that they lead would be able to interpret their leader's tendencies and interests.

Philosophically, content analysis uses the logic of Aristotelian; the positivistic paradigm. Therefore, Content Analysis is categorized as quantitative research. However, researches that use the methods of Content Analysis could also be applied in qualitative research. Content Analysis that uses qualitative methods, by Julien (Given, 2008, p. 120) is termed as "Latent Content Analysis", processing deductively, starting with deep and thorough text reading, and finding vague and hidden contents of the 
text. Methods of Content Analysis can be used in evaluating findings that are gained from the analysis itself. Hence, this method is not tied with theoretic perspectives such as phenomenology or grounded research.

In Krippendorff (2004), Janis stated that there are three types of Content Analysis how it is used as a framework, and those are; Semantic Content Analysis, Pragmatic Content Analysis, and Sign-Vehicle Analysis. This research focuses on procedure types of Sign-Vehicle Analysis that are done to categorize the content of a message based on signs that are found in psychophysics fields. Research categorized statements that are written by students in reflections, based on the frequency of the appearance of certain words or symbols that are stated in the assignments that became evidence of certain meanings towards some products. What is meant by "products" are farming activities in land owned by an organic farmer in areas of Sleman, DIY (Special Region of Yogyakarta). In the context of Sign-Vehicle Analysis, the psychophysics fields chosen is the meaning of "learning" which is related to awareness.

Furthermore, Krippendorf (2004, pp. 45-46) quoted Berelson (1952) in respect of the seventeen functions of Content Analysis methods, which a few of them are; To identify the intentions and other characteristics of the communicators; To determine the psychological state of persons or groups; And, to reflect attitudes, interests, and values (cultural patterns) of population groups. Concerning this research, those three functions are the most shown in SignVehicle Analysis applied on those written reflections.

Utilizing the Sign-Vehicle Analysis, the statements in the reflections written by the students, variety of word choices that appeared are identified to figure out the meanings that are carried on by the words that are chosen, that will later be connected to the increasing of the students' awareness toward the environment. The function of the Content Analysis method will eventually appear in identifying meanings and characters, psychological situations, and proving demeanors, interests, and values of the students' reflections (Jumal, 2018).

\section{FINDINGS AND DISCUSSIONS}

General Description of Lectures Basic Natural Science

The subject of Basic Natural Science is held to compensate with the knowledge of the students in non-exact sciences for them to understand how the natural environment works. That is why this subject is held only to teach students from faculties of social and humanities studies, such as Business, Theology, or English. The government has stated this subject in the Decree of the Minister of National Education (the pronouncement of Ministry of Education), number: 232/U/2000 in regards to Pedoman Penyusunan Kurikulum Perguruan Tinggi (College's Curriculum Preparation Guidelines) and Penilaian Hasil Belajar Siswa (Assessments of Student Learning Outcomes), Pasal 10 ayat 2 (article 10 paragraph 2), dalam kelompok mata kuliah Pengembangan Kepribadian (In groups of Personality Development Subject), that not all universities held this subject, for the sake of not cutting off on the subjects that are the point of each program that are studied. In the context of inspecting the arranged modules, the implementation of Natural Science Subject is ideally held as a team by people in charge of Mata Kuliah Wajib Umum (compulsory subjects) with philosophy and biotechnology or physics background. This matter is highly suitable for students to complement their perspec- 
tives in the environment and its relation to humanity.

In the first up to the fourth face to face meetings, this subject is commonly started with the topics that are related to how humanity reasons to the origin of knowledge, the origin of life were often stated and discussed, including the variety of nature lives, up to the environmental pollution problems. This subject eventually ends with how humans connect with their environment and how they take responsibility in taking care of their environment.

Assignments of farming in an organic farm are done related to humanity's responsibility to their environments. This activity is done to gain students' experience in making relationships with the natural environment by land processing, something that has never been done by modern youths that are mostly living in the cities now. Aside from that, this assignment is done specifically in organic farming to introduce students to natural fertilizer-based farming.

Before farming, students first listen to the explanation of farmers that are in charge of the land. After thorough explanations, students form groups and start to clear the land, choose seeds and locations for the plant. After the planting process is done, students are sent to water the seeds. Students are sent to visit their plants within a month period.

\section{Learning Strategies as an Important Factor in Achieving Learning Objectives}

Learning techniques and methods are important factors in the learning outcomes process. Learning methods focused on students or Student-Centered Learning are methods that are now highly recommended in the growth of learning outcomes. In the process, Students became the center of the learning objectives, teachers change their roles to facilitators, facilitating learning processes, and not the center of the learning process anymore.

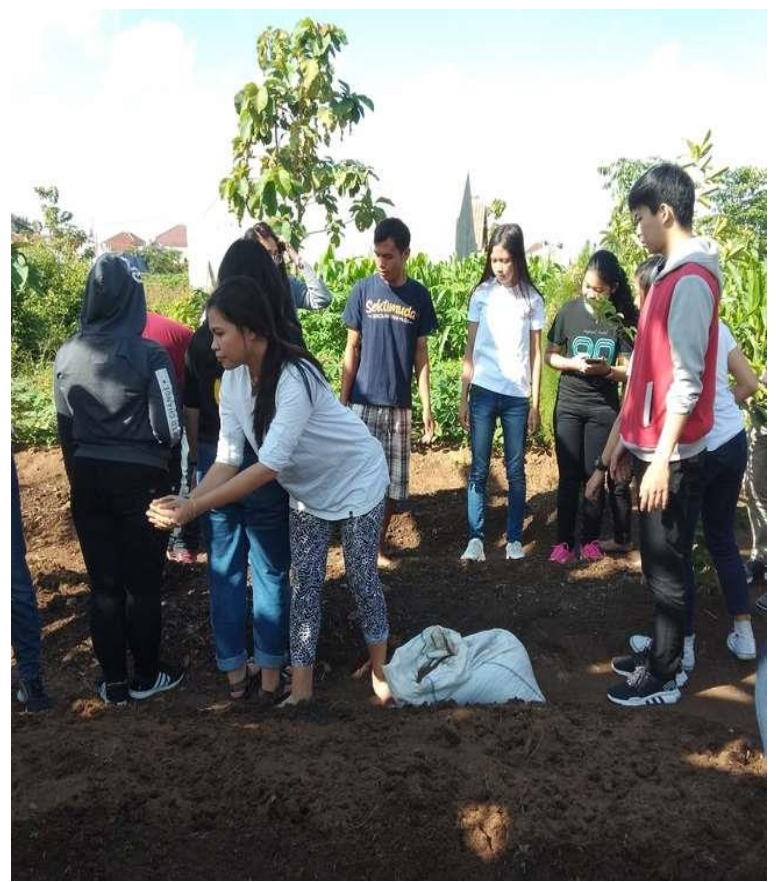

Figure 2. Students Doing the Instructions Given by the Farmers

The strategy of this learning process depends on the learning purpose formulation that contains the expected behavior. consequently, the purpose of this study highly depends on the suited techniques and methods. The purpose of knowledge and learning goals to have skills and behaviors have their own suitable methods. Knowledge aspects from Bloom are applicable, in how students' success in defining the word "environment," for affection aspect, students showed the ability of their concern on their environment, like "littering based on how the trash littered is considered."

In essence, every subject has its own characteristics, even though related subjects are on the same topics. For example, in colleges, several subjects are categorized as general subjects, termed as General 
Compulsory Subjects (MKWU). Each subject has different characteristics from other compulsory general subjects. Therefore, every learning method for each subject can be different. However, to bring students into a better understanding of what they learn, the assignments should have a practical aspect that fits what they have been taught above, and that is Student-Based Learning.

One form of learning is learning through projects or Project-based Learning (PjBL). Project-Based Learning is a learning model that uses a project or activity as the core of the learning, according to the 2013 Curriculum implementation module. Students explore, assess, interpret, synthesize, and analyze information to produce various forms of learning. This learning model is a learning model that departs from a background problem, that continues with an investigation for students to gain new experiences from real activities in the process. Then, they produce a project to achieve affective, cognitive, and psychomotor competencies. The final results of such an assignment may take the form of output, which includes, among other things, a written or oral report, presentation, recommendation, or reflection. The following sections discuss the results of this project.

\section{Student Reflection: Increasing Awareness of the Importance of Maintaining Natural Environment in Residence}

According to Fathurrohman (2015, pp. 121-122), the principles underlying project-based learning include the involvement of real-life tasks to enrich learning and problem-solving skills, group work, and self-management.

From the students 'writing as the final results of project-based learning, namely growing vegetables in organic farming, the principles mentioned above appeared in the students' statements.

Students who participated in this course were 40 (forty) Business faculty students from the 2017/2018 and 2018/2019 Class Management and Accounting study programs. The lecture is conducted in the odd semester 2019/2020, assuming that students have taken a minimum of 40 credits.

Before explaining the students' answers regarding the planting activity in the organic vegetable garden, they will first explain the problems faced. Not all of these sections were explained by the participants, however, from the few people who wrote them down, it was possible to learn about students' psychological pictures about this assignment.

The most common thing that was told in Reflection was about the very little farming experience. Statements that represent, for example, "We wear construction boots"; "I broke the hoe when I hit it to the ground, I was ashamed"; "We have too many seeds, so we lack land to plant them"; "We can't water our plants, because the sprouts haven't grown, even though we don't have time to wait"; "We are confused about how to plant one type of plant and another"; "There are some friends who find it difficult to hoe because they are not used to it"; ... Several times my hands got thorns, besides that, the weather at that time was very hot."

The matter of time management and technical preparation for the location was also an obstacle for some people. "... on the way, we parted ways, so we got lost and it happened that my friend and I didn't have an internet connection to use the map"; "Our difficulty is the different schedules we have, especially in choosing the day to do the planting task." That is what some people say about the technicalities they face. 
However, even though they experienced technical problems both before leaving for the activity and when doing it, students understood the situation. "..., But it's not a big problem for us to keep learning gardening...", "... in the end, they try and they can", or "... even so, our fatigue is gone, because we are treated to young coconut water which is taken directly from the tree. "

The experience of working together in teams as stated by Faturrochman above can give students confidence in their ability to learn new things and solve problems together.

After describing the students' expressions about the problems faced in preparation and planting activities, the following section is a student explanation about the benefits of the assignment. The following is an example of some reflective statements from students after participating in this project.

... "This activity also taught me mentally that preserving the environment is not difficult, it starts with ourselves and I am very impressed that Mr. Andi, where I do environmental care, teaches how hard work is, how patience is, and the results obtained from all it is sweet, I also become more forged when I go through the activities there, I am made aware that so far we have always been selfish and do not care for the environment, we also always damage the environment around us, always littering, I realize that all this time our food consumption is all mixed with dangerous chemicals, I became aware that from this activity, the environment and our bodies are connected, when your environment is healthy then what you consume is healthy and it provides good benefits for your body. The result of this activity is more towards slapping me to better protect the environment, maintain and preserve it, from all of that I would like to thank Mr. Andi for his knowledge, for the example of preserving the environment, giving lessons to me and my group how hard work is, teaching about the relationship of nature with us humans, I was very awakened and very motivated. This course benefits me because it gives me awareness, knowledge, experience that I don't necessarily get anywhere else. This subject is good because it forms us a generation who love, protect, nurture and preserve the environment." (Reinhard).

In just one paragraph, several positive expressions were found from students about their experiences in organic farming and at the end, about the benefits of the Basic Natural Science course. These expressions are as follows.

a. ...taught me mentally that preserving the environment is not difficult

b. I also became more tempered when I went through the activities there.

c. ... I was made aware that ...

d. ... I realized that ...

e. ... I became aware that ...

f. ... I say many thanks to Mr. Andi ...

g. This course is of benefit to me because it gives me awareness, knowledge, experience that I don't necessarily get anywhere else.

h. This course is good because it forms us a generation who love, care for, nurture, and preserve the environment.

In those 8 (eight) statements, there are phrases containing the word with the same meaning with aware 4 (four) times, namely, I was (made or become) aware (c and e), realize (d), and awareness (g). It was also found the word benefit $(\mathrm{g})$ and good $(\mathrm{h})$ which were meant for the IKD course. Finding those words can show the situation of students when experiencing the subjective gardening experience. This is related to the understanding of "the specious present" (Le Poidevin, 2019) which is the duration of time when the conscious state is experienced as "being in the present moment."

From the perspective of Philosophy, perception of time is a field of study in psychology, cognitive linguistics, and neuroscience that refers to the subjective experience or feeling of time as measured by one's perception of the unfolding events and the indefinite duration of them. From this statement, reflective writing activities 
forced students to rethink planting activities with their various processes. The duration between planting and reflecting writing activities creates subjective feelings and experiences from students to consciousness and awareness, which manifested in the word aware in their Reflection assignment.

Besides, the word aware, in addition to dealing with physiological processes of time, namely architectural elements in the framework of consciousness according to Solso, is also related to psychological processes, namely attention, wakefulness, recall of knowledge, and emotive (Solso, Maclin, \& Maclin, 2009). In architecture elements, as stated by experts, the perception of time cannot be done directly, but it needs to be reconstructed by the brain first, which is a physiological process.

The four psychological processes in the framework of consciousness can be explained as follows. Attention is the concentration of mental resources on things that are external and internal. It refers to student activities in the farming activities themselves. The wakefulness element refers to the conscious condition experienced by a person throughout his life, as experienced by students. Furthermore, recall of knowledge enables students to access knowledge through a process of recalling information both about themselves and about the world outside themselves, which in this case is the natural environment they are facing. The last thing is an emotive element which refers to affective things in consciousness which are shown in the students' word choices in their assignments.

The following are phrases of student expressions from all of the 40 (forty) students participating in this course regarding the experience of gardening in an organic vegetable garden which shows their atti- tude towards this experience. Those expressions are based on the question: "How did you feel about the experience?" and "Do you commit to continue to care for environmental care in the future?"

For the first question, some students stated it two to three times in their paragraphs with different variations of statements, as for the second question, not all participants answered the question or it was stated in a different form of expression, so it was not counted as a phrase.

\section{How do you feel about the experience?}

There were 4 (four) common phrases that showed the student's response to the assignment experience. The following Table 1 lists the four phrases.

\section{Table 1. Phrases on Feelings about the Assignment}

\begin{tabular}{llc}
\hline No. & Phrase & Total \\
\hline 1. & I realized & 24 \\
2. & I am very happy & 12 \\
3. & I know/understand & 7 \\
4. & I am aware of the importance & 5 \\
& ... \\
\hline
\end{tabular}

The examples of the complete expression are as follows.
a. "I became aware that from this activity our environment and our bodies are connected;
b. "I feel very happy because I can observe and be able to follow this change work activity "
c. "I know what to do "
d. "I am aware of the importance of caring for the environment."

For question number 2, 4 (four) phrases were found that showed the students' attitudes towards the continuity of experiences in the assignment. Question number 2 is as follows. 
2. Do you commit to continue caring for the environment in the future when you grow up?

The four phrases are stated in Table 2 below.

Table 2. Phrases on Concerns in Continuing Experiences from the Assignment

\begin{tabular}{llc}
\hline No. & Phrase & Total \\
\hline 1. & I am committed & 14 \\
2. & I (would, could) learn & 6 \\
3. & I (also) expect/hope & 2 \\
4. & I (really) want/desire to ... & 4 \\
\hline
\end{tabular}

An example of a complete expression starting with the four phrases above are these below.

a. "I also commit to continue to love the natural environment and its surroundings by sharing my experiences with my friends or relatives "

b. "I learned a lot, among others, the importance of maintaining and caring for the environment well"

c. "My expectations in the future, I hope that by implementing these changes in my family and other people, it can make them aware and care ..."

d. "I want to buy vegetable or fruit seeds that I can plant myself at home"

In the findings of the eight types of phrases mentioned above, the types of words chosen were those that had positive meanings, namely the words aware, happy, knowing, understanding in the first four phrases for question number one. The words committed, learn, expect, hope, desire in the second four phrases for question number two are words whose meaning is future- oriented. This is also reinforced by the modality words for will, want, conjunction also, as well as adverbial really which emphasize the verbs mentioned before.
The student's choice of words indicated "forward movement" into the future. The choice of words that are positive and future-oriented is not a choice of words for a moment, but it is a choice of words based on the time duration between one event (the planting of vegetables) and other events both before and after. Other events include writing Reflections, which through brain reconstruction produces these words. In this case, the conscious situation in the first four phrases of the group that have been interpreted as simultaneously conscious is also a conscious situation as awareness. In Indonesian language, the two words are only represented by one word, namely sadar, so it is possible to experience confusion in interpreting the conscious situation in the students. However, Hussain, et al. (Eds.). (2008, p. 298), stated that the concept is often synonymous to consciousness and is also understood as being consciousness itself. The two are synonymous. Thus, students' perceptions of time moving forward are also accompanied by the ability to directly know, perceive, feel, or be aware of the events that occur.

The four phrases of the second group that has been represented by the word committed with 14 (fourteen) is the total number, indicate a strong personal commitment. Personal commitment is based on the commitment of an individual or personal desires and expectations and, as such, is experienced as a free choice rather than as a compulsion (Agnew, 2009). Furthermore, Agnew explained that the word commitment which means "to continue to do something," and "subjective experience about the continuity of the relationship" is an important variable in relationship maintenance. It is a key motivational variable that shows respect for the relationship. This 
can be seen in the example sentences from Table 2, letter (a), "I also commit to continue loving the natural environment and its surroundings by sharing my experiences with my friends or relatives" From that sentence, the student already has a concern to maintain his or her relationship with the natural surroundings, namely" to continue to love "and" to share his or her experience with others." This is also related to Agnew (2009, p. 9) that people who have high commitment tend to have inclusive ways to involve other people in their conversations or actions. The word commitment also contains the meaning of caring for, the desire to sacrifice and to forgive. Thus, at least the fourteen students who stated that they were "committed" had a strong motivation to continue and maintain their relationship with the natural environment regardless of the situation.

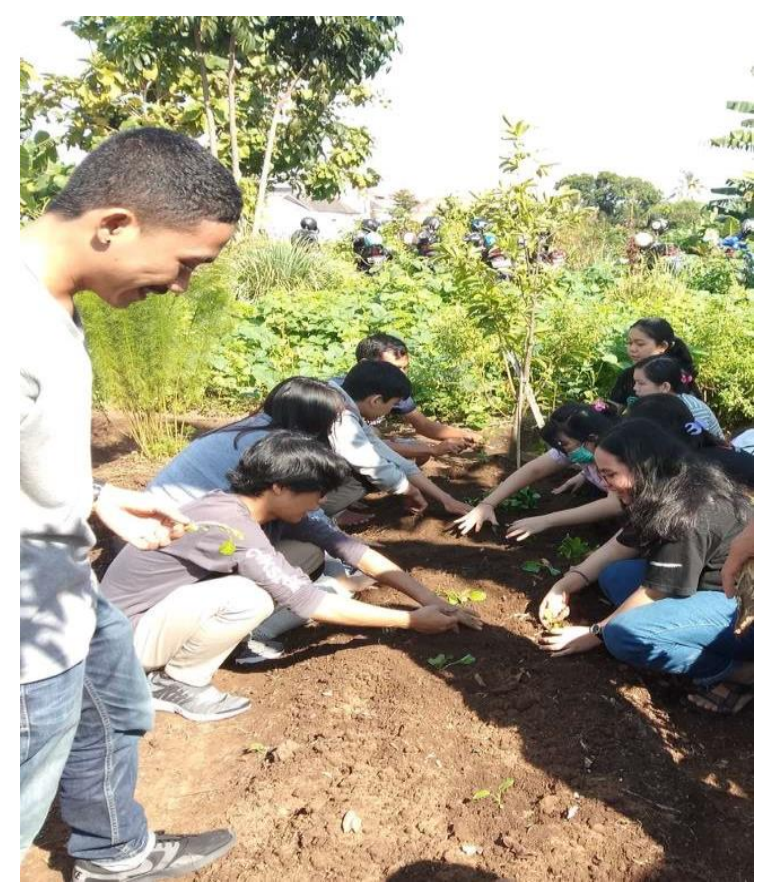

Figure 1. Vegetable Planting Practices The Learning Process for Understanding Reality

From the Sign-Vehicle analysis procedure in Content Analysis, which categorizes the contents of statements written by students in their reflections, it can be concluded that students have succeeded in reaching the 5th stage of the learning concept according to van Rossum and Hamer (2010, p. 6) which is a learning concept to understand reality. In this case, students try to develop their own thoughts. Peeters, et al. (2014) refer to it as learning for adults. Discussing aspects of the conceptual process, Marton and Beaty in van Rossum \& Hamer $(2010$, p. 7$)$ refer to the notion of expanding the views or horizons of students or opening their minds about various things. Learning is seen as a journey whose product is 'seeing things differently.' This learning process is then referred to as 'broadening the horizons.' According to van Rossum \& Hamer in another book (2008), the concept of learning from stage 1 to stage 5 is classified in the "learning to know" model (van Rossum \& Hamer, 2010, p. 26) that focuses on connections and various points of view. Students are in the stage of questioning "How do I relate to other people and other points of view." This can be proven through the eight selected statements from student reflections as follows.

a. "I became aware that from this activity our environment and our bodies are connected;

b. "I feel very happy because I can observe and be able to follow this change work activity."

c. "I know what to do."

d. "I am aware of the importance of caring for the environment."

e. "I also commit to continue to love the natural environment and its surroundings by sharing my experiences with my friends or relatives."

f. "I learned a lot, among others, the importance of maintaining and caring for the environment well"

g. "I hope that in the future I can implement these changes in my family and other people, can make them aware and care ..."

h. "I want to buy vegetable or fruit seeds that I can plant myself at home." 
The eight sentences above, taken from Tables 1 and 2, prove that students focus on connections and various viewpoints. They are questioning their relationship with other people or points of view. This can be seen in Table 3 below shows how students see themselves as connected apart from themselves (internally) with the environment outside themselves, namely the environment, family, others (externally).

\section{Table 3. Phrases "Learning to Know" and} Its Focus

\begin{tabular}{|c|c|c|}
\hline No. & Phrases & Phrase Focus \\
\hline 1. & $\begin{array}{l}\text { environment and } \\
\text { our bodies are } \\
\text { connected }\end{array}$ & $\begin{array}{l}\text { the connection between } \\
\text { the environment and } \\
\text { the body (physical) }\end{array}$ \\
\hline 2. & $\begin{array}{l}\text { observe and be able } \\
\text { to follow these } \\
\text { change work } \\
\text { activities }\end{array}$ & $\begin{array}{l}\text { the connection between } \\
\text { cognitive and affective } \\
\text { aspects of the personal } \\
\text { self with the change } \\
\text { process }\end{array}$ \\
\hline 3. & know what to do & $\begin{array}{l}\text { the connection of } \\
\text { cognitive aspects of the } \\
\text { personal self with } \\
\text { various points of view }\end{array}$ \\
\hline 4. & $\begin{array}{l}\text { the importance of } \\
\text { caring for the } \\
\text { environment }\end{array}$ & $\begin{array}{l}\text { the connection between } \\
\text { a sense of personal } \\
\text { empathy with the } \\
\text { environment }\end{array}$ \\
\hline 5. & $\begin{array}{l}\text { continue to love the } \\
\text { natural environ- } \\
\text { ment and its surr- } \\
\text { oundings by shar- } \\
\text { ing my experiences } \\
\text { with my friends or } \\
\text { relatives. }\end{array}$ & $\begin{array}{l}\text { the connection between } \\
\text { the affective aspects of } \\
\text { the personal self and } \\
\text { the social environment }\end{array}$ \\
\hline 6. & $\begin{array}{l}\text { the importance of } \\
\text { maintaining and } \\
\text { caring for the } \\
\text { environment } \\
\text { properly }\end{array}$ & $\begin{array}{l}\text { the connection between } \\
\text { three aspects: } \\
\text { cognitive, affective, } \\
\text { and psychomotor self }\end{array}$ \\
\hline 7. & $\begin{array}{l}\text { "with me imple- } \\
\text { menting these } \\
\text { changes in family } \\
\text { and others, can } \\
\text { make them aware } \\
\text { and care" }\end{array}$ & $\begin{array}{l}\text { connection of cogni- } \\
\text { tive, affective, and } \\
\text { psychomotor aspects } \\
\text { with various points of } \\
\text { view from the social } \\
\text { environment }\end{array}$ \\
\hline 8. & $\begin{array}{l}\text { "buy vegetable or } \\
\text { fruit seeds that I } \\
\text { can grow myself at } \\
\text { home" }\end{array}$ & $\begin{array}{l}\text { a personal-internal } \\
\text { connection from the } \\
\text { psychomotor aspect }\end{array}$ \\
\hline
\end{tabular}

Table 3 above proves that the focus of students includes three aspects introduced by Bloom, namely cognitive, affective, and psychomotor aspects. Thus, the plans of the students involve these three important aspects. "This activity is very helpful in communicating and working together in teams, helping to learn to be responsible for agreements, decisions, and work that must be done", concluded several groups about the whole of this activity.

\section{CONCLUSION}

After gaining experience in planting in a basic Natural Science course, students experience increased awareness of environmental care. Thus, it can be believed that the involvement of tasks in real life can enrich students in problem-solving skills, group work, and self-management. With the Sign-Vehicle Analysis, the writing of Reflections on experiences can be appreciated for its usefulness for the students themselves, both as a way to review personal experiences and as a way to express their deepest feelings that help reduce their anxiety. In the end, project-based assignments and writing reflections can identify the intentions and character of students, know their psychological situation, including reflecting students' attitudes, interests, and values. Future-oriented words and a strong motivation to continue and maintain a relationship with the natural environment give hope for a better future.

\section{ACKNOWLEDGEMENT}

I would like to thank the organic plantation management farmers who have been willing to accept and assist students in learning to recognize vegetable plants and practicing vegetable farming so that they have a new experiences and awareness of their relationship with nature. 


\section{REFERENCES}

Agnew, Christopher. (2009). Commitment, theories, and typologies. Department of Psychological Sciences Faculty Publications. Paper 28. Retrieved from http://docs.lib.purdue.edu/psychpu bs $/ 28$.

Fathurrohman, M. (2015). Model-model pembelajaran inovatif alternatif: Desain pembelajaran yang menyenangkan. [Alternatives innovative learning models: A design of fun learning] Jogjakarta: Ar-Ruzz Media.

Hussain, A. Aleksander, I., Smith, L.S., Barros, A.K., Chrisley, R., Cutsuridis, V. (Eds.). (2008). Brain-inspired cognitive system. New York: Springer.

Julien, H. (2008). "Content analysis” in Lisa M. Given (Ed.). The sage encyclopedia of qualitative research methods. Singapore: A Sage Reference Publication.

Jumal, A. (2018). Desain penelitian analisis isi (content analysis). [Research design of content analysis (content analysis)]. Jakarta: UIN Syarif Hidayatullah Jakarta. DOI: 10.13140/RG.2.2.12201.08804 .

Keputusan Menteri Pendidikan Nasional, Nomor: 232/U/2000 tentang Pedoman Penyusunan Kurikulum Perguruan Tinggi dan Penilaian Hasil Belajar Siswa, pasal 10 ayat 2. Retrieved from https://mpd.umsida.ac.id/wpcontent/uploads/2018/01/232u2000. pdf.

Krippendorff, K. (2004). Content analysis: An introduction to its methodology. USA: SAGE Publications.

Le Poidevin. R. (2019). The experience and perception of time. Retriefed from https:// plato.stanford.edu/entries/ti me-experience/.

Peeters J., De Backr, F., Buffel, T., et al. (2014). Adult learners' informal learning experiences in formal education setting. Journal of Adult Development 21(3), 181-192. DOI: $10.1007 / \mathrm{s} 10804-$ 014-9190-1.

Solso, R.L., Maclin, O.H., Maclin, M.K. (2009). Psikologi kognitif. [Cognitive psychology]. Edisi ke-8. Jakarta: Penerbit Erlangga.

Suja, I.W. (2015). Integrasi pendidikan karakter ke dalam kurikulum ilmu alamiah dasar. [Integrating character education into curricullum of basic natural science]. Proceedings Seminar Nasional FMIPA UNDIKSHA V. 131136. Retrieved from https://ejournal.undiksha.ac.id/index.php/semna smipa/article/view/10267.

Surahman, Rachmat, M., \& Supardi, S. (2016). Metodologi penelitian. Jakarta: Pusdik SDM Kesehatan, Kementerian Kesehatan Republik Indonesia.

Van Rossum, E.J. \& Hamer, R. (2010). The meaning of learning and knowing. Rotterdam: Sense Publishers.

Yani, I \& Susanto, L.H. (2019). Penerapan pembelajaran aktif berbasis games dengan penugasan mind mapping untuk meningkatkan hasil belajar Ilmu Alamiah Dasar di Program Studi Pendidikan Bahasa Inggris, FKIP. [Application of game-based active learning with mind mapping assignments to improve learning outcomes of Basic Natural Sciences in The Department of English Education Program]. Universitas Pakuan. Pedagonal: Jurnal Ilmiah Pendidikan, 3(1), 43-55. Retrieved from http://journal.unpak.ac.id/index.php/pedagonal. 